\title{
An Attempt to Shift Commodified Archaeological Practices in Taiwan through Community Engagement
}

\section{Wang Bo-Chiao 王柏喬, Chung Kuo-Feng 鍾國風 \& Nicolas Zorzin}

National Cheng Kung University

\begin{abstract}
Archaeological practice in Taiwan, an island located in East-Asia, is deeply influenced by Han Chinese culture and by the implementation of capitalistic approaches to dealing with archaeology that developed thanks to the ideological influence of the United States or the United Kingdom. This article aims to introduce a case study of an experimental approach to public archaeology carried out in Taiwan, which invested substantial effort to being self-reflexive.

Since the 1980s, archaeological practice and the preservation of archaeological heritage in Taiwan has been practiced within the framework of contract archaeology. However, although the number of instances of commercial archaeology increased exponentially, the number of trained archaeologists remains scarce. In this context, archaeologists were trapped within an extractivist economic system that only served the interests of developers. Overwhelmed by massive amounts of work, the quality of the archaeological practice inevitably decreased. In reaction, some archaeologists are now seeking an alternative by adopting more reflexive approaches, which include public archaeology and community engagement.

This article presents a brief introduction to the development of cultural heritage, archaeology, and public archaeology in Taiwan, followed by a case study from the site of the Old City of Zuoying (zuoying jiucheng, 左營舊城) (Southern Taiwan). By sharing our experiences, we aim to emphasise the significant positive aspects that emerged from a community-based and experimental approach, but at the same time to highlight the difficulties and failures we faced with this approach.
\end{abstract}

Keywords: Public Archaeology; Community engagement; Historical site of Old-City of Zuoying (zuoying jiucheng, 左營舊城); Reflexivity; Taiwan.

\section{Introduction}

Describing the full breadth of the term 'public archaeology' and implementing it in practice is a challenging undertaking. As illustrated by Bonacchi \& Moshenska (2015: 1), it is a constantly 
evolving field that explores the numerous challenges faced by archaeologists in their relationship to the public (Fritz and Plog 1970: 412; Holtorf 2007: 51-52; Merriman 2004: 7; Okamura and Matsuda 2011: 4, Pyburn 2011: 29-39). In response to these challenges, several criticisms, tensions, flaws, and failures have been identified (La Salle 2010; LaSalle \& Hutchings 2016; Zimmerman 2008: 55-86). Indeed, some have considered this form of "collaborative" archaeology with the public, especially in a colonial context (e.g., in Canada, the USA, Australia, and Taiwan), as only serving the 'colonial enterprise'. According to these critics, public archaeology aims to create a 'co-optation and a dependence' of Indigenous people towards their pasts, their culture and their current lifeways, paradoxically seeking for 'liberation' (LaSalle \& Hutchings 2018: 1).

The definition of 'public archaeology' we utilise in this contribution corresponds more accurately to an archaeological project which involves the genuinely collaborative, integrative, inclusive, unavoidably conflictual, messy, and unpredictable involvement of people. We concur with the idea that community engagement in archaeology should "serve the marginalized and challenge the dominant" (McGuire 2008: 8). By extension, and to be more precise in our choices and orientations within public archaeology's sphere of actions, we would like to focus essentially on a 'community-based archaeology' in line with the suggestions of Overholtzer (see also Atalay 2012; 2006: 284; Little and Shackel 2007; Colwell-Chanthaphonh and Ferguson 2008). This definition emphasises the primary necessity of 'engagement' with local citizens and aims to return to them 'some [if not all, in the long term] of the control over and benefits of the process of archaeological research' (Overholtzer 2015: 51).

With this framework in mind, we are also particularly aware of the complexity of the interconnections between the numerous actors involved in an experimental community-based project. As a result, we are conscious of the difficulty of defining a 'community' as individuals belong to 'multiple' communities, as archaeologists have the tendencies to create 'imaginary' ones. Moreover, it is not only locals and descendants who belong to a community but also individuals in a larger network who use their political and economic power to serve specific interests (Pyburn 2011: 29). Therefore, in our subsequent analysis we give particular attention to power relationships, ethical issues, and control over the knowledge production not only with, for, and by the residents, but also within the archaeological team itself.

Part of practising an intellectually honest public archaeology means not only accepting the loss of control over the management of the archaeological process, but also the necessity to share this with the public primarily concerned by it. This approach opposes the practical obligations of a commodified 'commercial archaeology', also called 'contract archaeology', which, as will be discussed below, largely dominates the practices current archaeological network in Taiwan. As such, in conducting our case-study in Taiwan, we expected to see a range of internal and external tensions and conflicts resulting directly from the current political-economic configuration of archaeology. We will attempt to deconstruct these tensions by showing how archaeology is not a technical extraction of valuable 'things' from the past, but rather a theatrical choreography that manifests the socio-ideological and cultural oppositions in present society.

\section{Exploring Cultural Heritage in East-Asia}

As stated by Matsuda \& Mengoni (2016), even though critical cultural heritage studies are abundant across the globe, treating East-Asian heritage as 'a construct or a process' is a concept that remains a relatively recent topic of debate. In East-Asia self-critical approaches are not necessarily common and not necessarily easily implemented (2016: 2). There are many reasons why this critical approach has been absent, one of which is the effect of Confucian philosophical values; this often results in the avoidance of any form of criticism, especially towards elder 
scholars. However, two other neutralising factors may have played larger roles against deconstructive approaches: 1) strong nationalist resurgences (Nakano \& Zhu - 2020; Zorzin 2020: 274), and 2) a generalised commoditisation of heritage (Blumenfield \& Silverman 2013; Kendall 2010; Linnekin 1997; Zorzin 2020: 276-277).

As cultural heritage became the stage for 'soft-power' battles between Japan, South-Korea, China and the emerging South-East Asian nations in a global competition for influence, these powers constructed and actively disseminated certain expressions of nationalist cultural heritage. These were targeted at both domestic and international audiences (Nakano \& Zhu 2020: 870). However, since its exclusion from the United Nations in 1971, the insular nation of Taiwan was left with only one option: to target its domestic audience. Until the late 1980s and the beginning of the democratisation process, the Kuomintang party-state (KMT) maintained a well-defined national narrative for the population of the island. This was exclusively rooted in continental Han China, and ultimately aimed at the reunification with China under the KMT's initiative. In opposition to the Sinicization approach taken by the KMT's dictatorial regime, a new dominant narrative appeared after 1987 that focused instead on what could differentiate Taiwan from China. This consisted of emphasising Taiwan's marginally Dutch and Spanish heritage, its mainly natural landscape, as well as Japanese and Aboriginal cultural heritage as main identity markers (Amae 2017: 256-257). While this overview necessarily simplifies the dynamics at play in Taiwan's history of cultural heritage, the authors feel it necessary to remember, understand, and reflect upon the current cultural and geo-political landscape.

Currently, the idea of Cultural Heritage as being increasingly commodified in East-Asia is not only concerned with the fact that a narrowly defined heritage is often valued in terms of its ability to generate profits or to be financially self-sustained, especially those related to tourism. In terms of archaeology, this also means that the excavated cultural heritage would be processed according to a capitalistic set of ideas. Such a framework prioritises development above all, resulting in the steady destruction of cultural heritage (or so-called 'protection' by preservation in records only) unless the archaeological remains can be used to serve political agendas. This method supports specific narratives and interests, whether consciously or not. In the case of Taiwan, we are thus dealing with the necessity of starting a double decolonisation process: 1) from the capitalist framework and from the resulting commodification of archaeology (which is the focus of this contribution), and 2) from nationalist tendencies within the management of cultural heritage.

Consequently, implementing an experimental community based-project in Taiwan has as its main objective to challenge the current practices and current organisation of commodified archaeology in Taiwan. This involves exploring alternative and emancipatory practices for both archaeologists (ourselves) and local communities. As such, we aim, to initiate a self-critical reflection on how academic archaeology is practiced within a contractual industry.

\section{The recent development of public archaeology in Taiwan}

As mentioned above, Taiwan is a bipartite society composed of a population using Austronesian languages (approx. 3\%) and a later migration of various groups of Han Chinese $(97 \%$ of the current population of Taiwan). This Han Chinese ethnicity is composed mainly of Holo, Hakka, and Mainlanders. There is also a small portion of new immigrants moved to Taiwan for marital or work purposes ${ }^{1}$. Yet, the early years of Taiwanese archaeology were impacted by foreign

\footnotetext{
${ }^{1}$ Land and People. Executive Yuan. Retrieved from World Wide Web https://www.ey.gov.tw/state/99B2E89521FC31E1/2820610c-e97f-4d33-aa1e-e7b15222e45a [Accessed on 6 November 2021].
} 
colonial powers within a rising global economy. From Japanese colonisation (from 1895) to the ROC nationalist reign's (from 1945), until the democratisation after the lifting of Martial Law (since 1987), archaeological research in Taiwan has been dedicated essentially to structuring Taiwanese prehistory (Kano 1952; Sung 1965; Chang 1977). However, most discourses were dominated by a Sino-centred ideology (Liu 2006), which places the origin of Taiwan's prehistoric populations and culture in Southeast China. This illustrates that in the early days of research, archaeologists in Taiwan lacked the necessary reflexive thinking and academic distance to place Indigenous people at the core of their research. Subsequently, this meant that there were few opportunities for Indigenous groups to conduct excavations, manage their cultural heritage and interpret it from their own standpoints.

With the democratisation of Taiwan and larger trends toward diversity in the 1980s, local historical archaeology research programs begun to emerge (Chang 1986). It marked the beginning of research on early Han Chinese in Taiwan, on "Taiwanese Plains Indigenous Peoples" (Tsang et al. 1988), on the archaeology related to ancient populations in the Penghu Archipelago, as well as on the history of Han Chinese colonisation. This period also marked the moment when the economy of Taiwan shifted from a national planned economy to a high-tech, international, and free market economy. The Indigenous population of Taiwan were forced to integrate into the capitalism system, resulting in Indigenous communities losing their land, being economically exploited, as well as politically and culturally marginalised (Kuan 2014 24-33). In 1987, the Association of Advancement of the Rights of Taiwan Indigenous Peoples (台灣原住民族權利促進會) established the Declaration on the Rights of Taiwan Indigenous Peoples. This document defined Indigenous rights, such as the right to an adequate standard of living, land ownership, self-determination, and cultural rights.

The rapid economic development of Taiwan triggered tension and conflicts between the necessity to construct large-scale infrastructure projects and the necessity to preserve cultural heritage. In response to these developments, archaeological units existing in academia carried out large-scale rescue archaeological projects, such as: 1) the construction of Taitung's train station on the Beinan site (1980); 2) the sewage treatment plant of Bali built on the Shi San Hang site (1990); and 3) the development of the Southern Taiwan Science Park (1995). Despite the abundance of artefacts exhibited and the opening of numerous museums at the national and municipal level, the narratives mostly focused on prehistory (i.e. pre-Han colonisation). The presentation of prehistoric materials and their associated narratives were cultural-history centred, or they simply aimed to commodify Indigenous archaeological material to promote economic development. Rarely did these narratives present the Indigenous communities' perspectives and interpretations of the archaeological heritage. With the gradual increase in the intensity of development, several private archaeological service companies were founded after 2010. The practice of rescue archaeology began as a social responsibility carried out by the state through academic units, but the increasing economic pressure allowed the state to make space for private units. It is then that the management of archaeological heritage, supposedly aimed at serving public interests, shifted towards a more capitalistic and managerial logic.

In the 1990s, the flourishing of ethnohistorical and multi-perspective interpretations of Taiwanese archaeology influenced archaeologists to look beyond the Neolithic period and to dedicate more time and energy to the historic period of Taiwan. Research into the protohistorical period, which centred around the link between successive occupations of Austronesian-speaking communities and Han colonisation, started to receive more attention (Liu 1995, 2005). However, the proto-historic sites that closely related to the recent settlements of Indigenous peoples of Taiwan were usually abandoned due to conflicts with colonial powers or relocated by force by colonial policies, after the $17^{\text {th }}$ century. These "abandoned settlements" became symbols of the Indigenous people's cultural legacy and evidence used to define 
traditional territories. There were several researches on "abandoned settlements" carried out by archaeologists after 2000s from different research perspectives, includes cultural history, settlement spatial analyse, to more inclusive archaeology which involved indigenous communities (Liu et al. 2000; Kuo et al. 2010; Yen \& Hsu 2013; Chen 2005, 2013; Wu 2013).

In recent years, Indigenous peoples have continued to fight for greater say in their land rights, heritage management, and on constructing narratives on the past. They have demanded a decent standard of living and for the development of disfranchised communities. In response, "The Indigenous Peoples Basic Law" (2018) specified that archaeologists active on the land of Indigenous peoples, "shall consult and obtain consent from indigenous peoples or tribes, involve them, and share the results with them." Archaeologists began to face various conflicting choices while recognising Indigenous claims, such as the Katripulr tribe of Beinan refusing to relocate their ancestral tombs. Similarly, the Kunuan tribe of Bunon asked for the repatriation of their ancestral human remains, as well as the designation and preservation of the Ciyakang archaeological site, including the Truku recognition of their land rights. At this point, archaeologists began to re-examine their archaeological methods and ethics and reflected on how archaeological activities negatively affected not only fundamental Indigenous rights, but also damaged the views Indigenous people had of archaeology and of archaeologists working on their ancestral heritage (Muyard 2016).

Archaeologists in Taiwan continued to reflect on the contemporary significance of public and Indigenous archaeology, the methodology of which ranged between forms of ethno-archaeology (Chen 1996, 2003; Chung 2014), to more archaeo-ethnographic approaches that focused on mutual-benefit, reflexivity, and cooperation (Wang 2020). As a result, archaeologists are now expected to cooperate with local communities on research aims, methodology, and the preservation of excavated artefacts (Zimmerman 1997). At the same time, archaeologists are placed in the position of mediator between the multiple and divergent interests surrounding ancient heritage (Shanks 2005), notably in terms of identity, ownership, and repatriation.

Yet, despite these significant developments, community-based archaeology did not develop in the historical landscape of Taiwan. As such, Han communities have not been involved much in the historical archaeology of Taiwan, as if there was no such a thing as Taiwanese/Han archaeological heritage. This is in direct opposition to the glorious Chinese dynastical cultural heritage, mostly architectural, which was valued, preserved, recreated, or invented during the KMT dictatorship and afterwards. Only some Japanese colonial architectural heritage has attracted attention in the last few decades but with a rather independence (from China) (re)affirmation agenda. This position emphasises the diversity of identities in Taiwan or is driven by an economic agenda towards profitable tourism (Zorzin 2020:281-282), similar to what happened with Indigenous heritage. This is a challenging situation as it denies the specificities, complexity, and great diversity of the waves of Han migration since the $17^{\text {th }}$ century until today, as well as the arrival of 1.2 million mainlanders (Chinese) in 1948-49. It also overlooks the slow but steady wave of South-East Asian migrant-workers (and spouses) currently entering Taiwan. As a result, a gap in the development of public archaeology exists in historical and contemporary archaeology; filling this gap was one of the motivations of our choice in the archaeological site of Zuoying.

\section{Community-based Archaeology as a reaction to commodified archaeological practices}

From 2016 to 2020, a series of community archaeology projects were carried out in "Old City of Zuoying (OCZ - zuoying jiucheng, 左營舊城)” site also known as “Old City of 
Fongshan County from the Qing imperial era (qing fengshanxian jiucheng, 清鳳山縣舊城)” site (Chung et al. 2017; Liu et al. 2021). This was done by several archaeologists from the National Cheng Kung University (NCKU), and assisted by professional field archaeologists with years of experience in contract archaeology. The aim was to revitalise the OCZ site and surrounding area through a public archaeology project (Liu et al. 2021:1).

The dissatisfaction experienced by the authors in commercial archaeology as discussed above pushed us to seek alternatives to our present archaeological practice. Even though it is unlikely for commercial archaeology to cease to exist in contemporary society anytime soon, it is important to have space to develop and practice a more ethical and reflexive archaeological practice. Here, we argue in favour of three research targets based on our past observation of archaeological work in Taiwan:

\section{Breaking bierarchy within the archaeological team}

In Taiwan, it is common that academic archaeologists work in contract archaeology, as academic archaeological units also carry out contracts. Contract archaeology is dominant within archaeological practice in Taiwan, conducting approximately $90 \%$ of all archaeological projects done each year, as evaluated by Zorzin (2021a) through some limited examples. Although the "polluter-payer" principle that applies to contract archaeology provided abundant budgets for rescue activities, the market economy created a detrimental environment as developers became, de facto, the employers of archaeologists. Developers decided which archaeological team they would work with, and define schedules, locations, and scopes of the work. In this context, archaeologists became poorly inclined to conduct research, as they had to excavate certain areas based on the plans of developers, rather than on an area's archaeological potential and possible significance. The resulting archaeological data would be unavoidably biased due to the choice of the location; even if the information extracted from the excavation was considered good enough for research, an archaeologist could not stop development and preserve the rest of the site. Archaeologists have no choice but to "clean" the site (as requested by the contracts signed with developers), and to extract all the contexts and materials within the designated area in a very limited time. As expected, this resulted in a questionable quality of excavation and records.

Furthermore, it is well known that archaeologists in Taiwan endure heavy workloads, preventing them from dealing adequately with the ever-increasing demand for contract archaeology (Zorzin forthcoming). This phenomenon further alienates researchers from conducting field work, as a limited number of archaeologists manage many cases simultaneously. The model currently established in Taiwan seems to correspond to an extractivist one as defined by Hutchings (2018: 71; See also Hutchings \& La Salle 2015: 710). In this model, academic archaeologists hire dozens of workers and several assistants to optimise excavated volumes and surfaces and to conform to the developer's schedule: all of this occurs without the archaeologist being physically present (or only occasionally) on site (Zorzin forthcoming).

As such, a pyramidal system was formed to adapt to this kind of practice; archaeologists with academic training possess the power of distributing budgets, interpreting 
archaeological data, and accessing academic knowledge. In the meantime, assistants and laborers who carry out fieldwork on site might prefer not to express their opinions and not argue with archaeologists when their observations and opinions differed from those of the archaeologists. We believe that this kind of practice damages the quality of archaeological work and forms an exploitative environment. Therefore, we believe that the practice in OCZ should seek to break this kind of social hierarchy, urging archaeologists to work and share knowledge with the community members who joined the team.

\section{Empowering team members by granting them access to knowledge and giving them a voice:}

With regards to the issue mentioned above, we propose a practice that focuses on building an environment where knowledge is shared within the team, which further encourages members to explore local knowledge from their daily lives and historical memories, and which brings the latter further into the interpretations.

Today, one of the major discussions concerning archaeological practice in Taiwan is to rethink archaeological knowledge acquisition (Hodder et al. 2000: 18). Ideally, both field professionals and academic researchers should possess some knowledge about stratigraphy, geology, epigraphy, material analysis, local history, and local customs to make more appropriate decisions during the process of knowledge acquisition, (i.e. archaeological survey and excavation). The result is that an archaeologist will better understand the collected information. Some of these skills can be learned by academic training, some can only be acquired by years of field-experience, but others must be learned by living near the site and interacting directly with local communities for years. As Hodder proposed, adopting a reflexive approach (2000: 5-9), which integrates staff members with different specialisations, and which has a fluid database to link participants in the project, leads to better strategy and decision-making in research. Hence, we invited and hired local community members into the team as we believe local knowledge is essential in archaeological research, especially at a historical site like Zuoying Old City. Furthermore, we not only invited some community members to join the team, but also sought collaborations with multiple communities.

\section{Entering the community and fostering collaborations}

By adopting a community archaeology approach and by building a collaboration between archaeologists and local communities, we expected to break the chains of the exploitative and extractivist model. Such a project was our attempt to define an alternative and a de-commodified path for archaeology, namely one that is decolonised from capitalist logics and constraints (Zorzin 2021: 9).

This pilot project was designed as an example of community-based research. Rather than merely acquiring archaeological data and doing artefact analysis (following the traditional process of archaeology in Taiwan), we emphasised on interacting with people, and with living and working communities around the site. Communities have indeed very different interests, perspectives, and agendas toward the site compared to the ones of the archaeological team. Thus, as the archaeologists participating in this study, we inevitably needed to: 1) reposition our role in the project and challenge our position of power to produce interpretations and acquire and distribute resources within a team; and 
2) delineate the values people attributed to the site, i.e., what archaeology means to them, and how it may affect them. Being reflexive in this archaeological project aimed to understand how archaeology relates to the communities within the current working model in Taiwan, and to find an alternative and potentially more sustainable model for archaeology.

\section{Research Methodology and Ethical Principles}

Through the years (2016-2020), the archaeological project at Zuoying was recorded through participant observation and through interviews (Wang 2020). Over 400 interviews were conducted, including of: 1) archaeologists and field workers; 2) local researchers; 3) local elders; 4) officials of the local government; 5) residents from the surrounding area; and 6) people who participated in our public outreach activities.

The interviews followed two forms, the "scheduled standardized form" or the "nonstandardized form" (Denzin 1970: 123-126). Most of the interviews were nonstandardised interviews conducted during fieldwork, which captured the voices and reactions on site (included the voice of the interviewer) and put the interviewees in a friendly, comfortable environment (Palmer 2001: 309; Dezin 2009: 126). All interviewees were well-informed that the conversations were being recorded and that the records would be used in a specific research framework, and for both, interviewees gave their consent. The anonymity of the interviewees and access to their records was also part of our ethical engagement.

\section{The Archaeological Site}

Zuoying Old City comprises an area within the city wall built during the $19^{\text {th }}$ century Qing imperial period in Kaohsiung City (Fig. 1). However, human activity in this place dates back to the early Neolithic period. In the $17^{\text {th }}$ century, it became a HanChinese settlement inhabited by Han immigrants during the Koxinga regime and the Manchurian empire of Qing. The remaining stone city wall was designated as a national monument in 1985, but the area within the wall, apart from a small portion (ca. 1 hectare within the approximately 51 hectares of the site), remained undesignated until now.

The relationship between Neolithic human activities and the Han Chinese settlement built in the 17th century remains unclear. Even though material from the late Neolithic period (2000-350B.P.) was found in the surrounding mountain area, none has been discovered within the OCZ site so far (Liu 2008: 40). It is possible the Neolithic group who occupied the OCZ area left around 2000 B.P. for unknown reasons, or the material from the era remains undiscovered.

It is also possible the Han Chinese population had already arrived and built the settlement during the Koxinga period (1662-1683), but there is no clear documentation or archaeological evidence so far. However, materials from that period (such as porcelains) can be seen within Qing era archaeological contexts.

The Han Chinese settlement became one of the political and economic centres of southern Taiwan after the Qing empire appointed it to be the capital of Fongshan County. This also made the settlement the target of rebel forces against the Qing 
Empire, which resulted in the city being burned down twice during the $18-19^{\text {th }}$ centuries. In 1788, the empire moved the capital to another settlement, later called "Fongshan New City", and named the old capital "Old City". On several occasions the empire considered returning the capital of the county back to Zuoying. However, this never happened, despite the fact a city wall was built in 1826 and is still visible in OCZ.

Today, this four-kilometre-long stone wall symbolizes the so-called "glorious" past of Zuoying, as the last attempt to bring Zuoying back its prestigious status of political and economic centre. In the early $20^{\text {th }}$ century, the Japanese Empire built the contemporary centre of Kaohsiung city, off centring Zuoying. Later, the settlement within the wall was demolished by the Japanese to militarize the area for WWII. Yet, the 'old city' settlers did not move far away from their ancestral home, and many of their families still live around the area.

Members of the neighbourhood sarcastically define Zuoying as the poor area of Kaohsiung City, suggesting that this was the reason Zuoying "remained undeveloped". Therefore, precisely because of its 'underdevelopment', cultural heritage could be preserved, such as old houses and most of the stone city wall in the area. As a result, community members expected the promotion of their heritage to help them to boost the local economy through tourism.

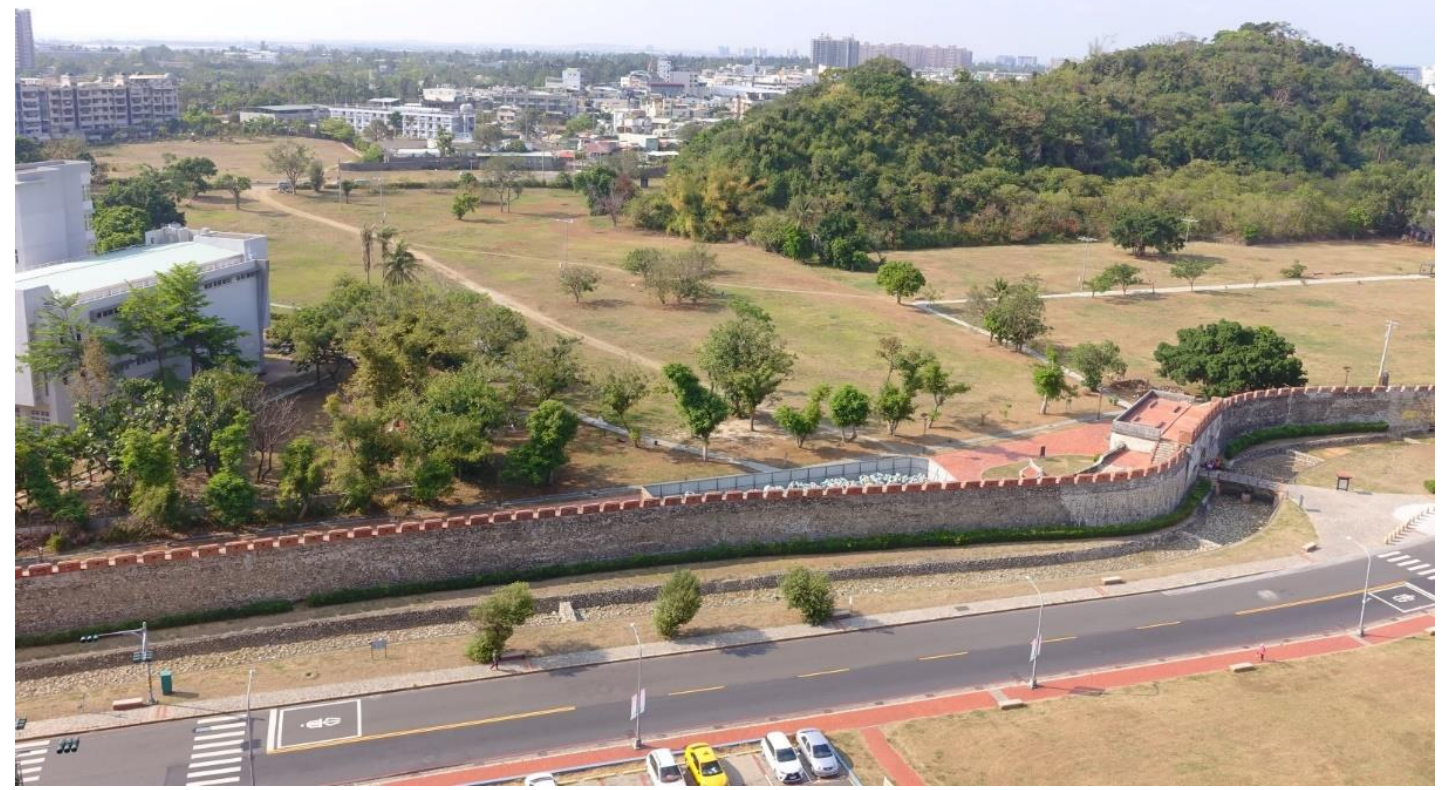

Figure 1. A distant view of Old City of Zuoying site (OCZ site, 4 April 2017, Photographer: BoChiao Wang).

All in all, some community members appeared to be connected to the site, fully aware of the significance of heritage and its connection with their ancestors. Furthermore, they were aware of potential advantages they could gain from it, both economically and socio-culturally. Therefore, it was crucial for us to understand the variety of values the 
communities attached to the site, in order to understand their links to the site and build collaborations.

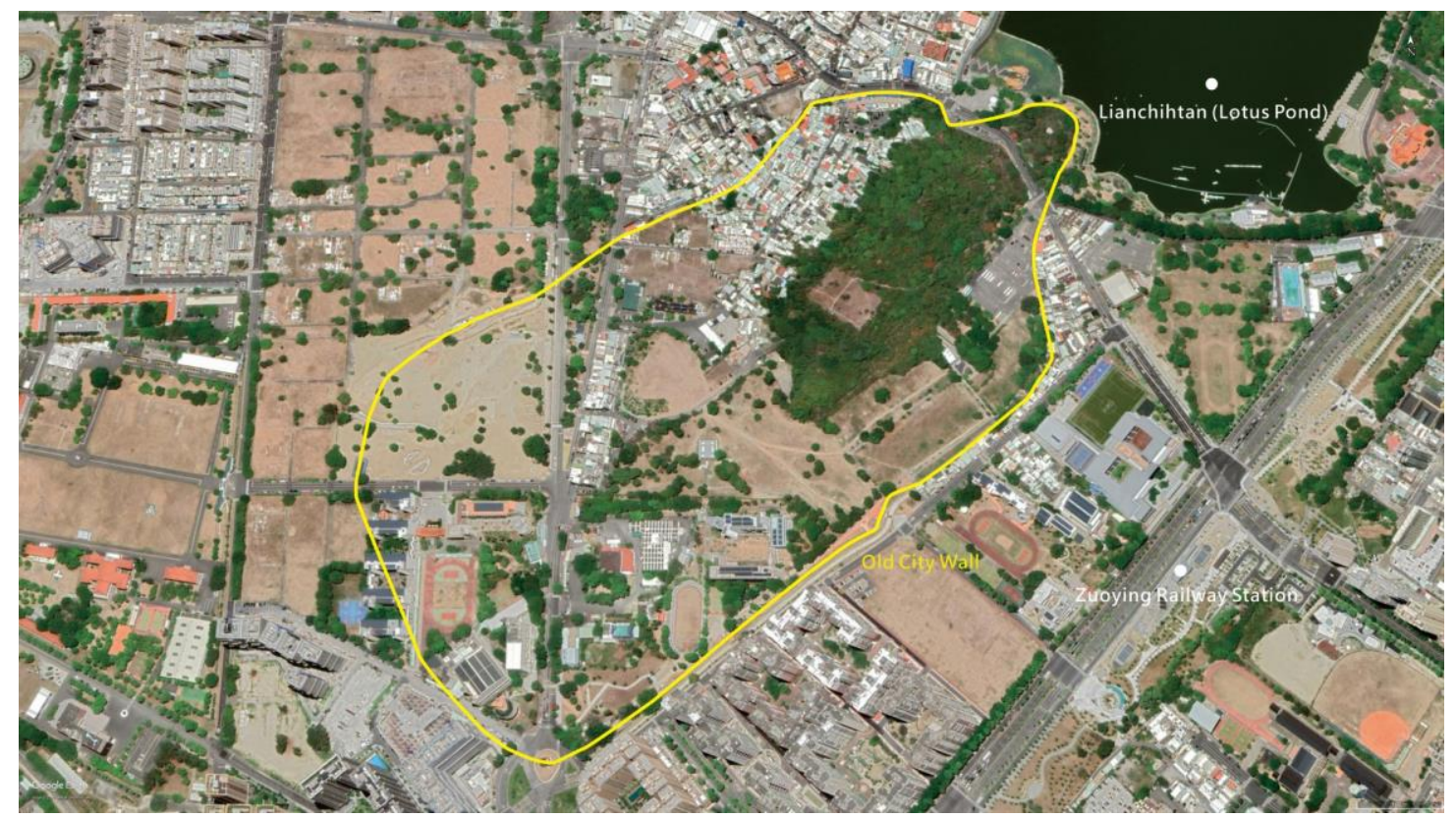

Figure 2. Satellite image of the OCZ site. Yellow line represents the location of the stone wall (Google Earth pro-2021, edited by Bo-Chiao Wang).

\section{Archaeological Research in the Old City of Zuoying site}

Through the years, the nature of archaeological research at the site of OCZ followed the larger trends of archaeological research in Taiwan from the 1980s to the present day. In 1988, archaeologists from the Academia Sinica (the principal State research centre since 1954) started a research project in OCZ, examining the relationship between "Taiwanese Plain Indigenous Peoples " and Han Chinese immigrants during the contact period (Tsang et al. 1993). During the 1980s, there were very few contract-archaeology projects in Taiwan, and archaeologists mainly focused on academic questions.

As mentioned earlier, along with the establishment of the Cultural Heritage Preservation Act (1982) and the Environmental Impact Assessment Act (1994), a series of rescue archaeology and archaeological cultural heritage evaluation cases were carried out between the 1980s to the 1990s. An evaluation of the site of OCZ and of its potential significance was carried out in 2001 (Ho et al. 2001), to avoid damage from future developments. In 2004, the development of a residential building was planned on the site, but it was suspended after an initial archaeological excavation (Liu et al. 2004). This excavation unearthed abundant materials from the early Neolithic to the historical period, which led to its designation as a municipal archaeological site in the same year. In 2014, the demolition of the military settlement revealed part of the foundation of the city wall. After a local community's appeal to the local government to carefully examine the ancient structure, archaeologists were hired to document the current state of the wall (Yen 2014, 2015). This succession of events at the OCZ site showed that most of the archaeological activities were purely research assessments, excavations, and analysis, and 
no further outreach to the diverse communities closely related to this place was attempted. Although this situation was standard practice in Taiwan, the archaeologists involved suggested instead that the discipline should build stronger connections with contemporary society.

As a result, NCKU archaeologists established a public archaeology project between 2016 and 2020 by excavating trenches based on historical documents and on some information gathered from local communities. In the middle of this research project, we also collaborated with local researchers, as we realised that they had already conducted a great deal of research in historical archives, making some of our own pilot research plans redundant.

\section{The communities of Zuoying - not so distant of a past}

In a discussion about archaeology, Ian Hodder once wrote: "A closely related issue is that the distant past in many parts of the world may have no present communities which can stake a direct claim" (Hodder 2003: 56). However, at the OCZ site, we had the privilege to meet diverse stakeholders, such as the descendants of the ancient settlers, many of whom hold some memories of the place transmitted through generations. Local amateur historic researchers were also intensely dedicated to the rich history of the OCZ site, which contributed to making it a well-known piece of cultural heritage in Taiwan. This local involvement in research is particularly valuable for archaeological research, as the knowledgeable amateurs also brought challenges to archaeologists. Local elders or amateurs knew the site in great detail thanks to years of experience, and they had their own perspective on history and on the site's landscape. They could examine historical documents, conduct ethnographic interviews with the old settlers, measure and do cartographic work on their own, and had even published their research results (Liaw 2014; Kuo \& Liaw 2018).

During our collaboration with the communities, the contrasting opinions were quite perceptible. The archaeological site, artefacts, or even structures deemed to be "cultural heritage" from an academic perspective may not be identified as such by local elders. They might be confused or even angered when research outcomes conflict with their memories. When we told the elders who came to visit the excavation trench that we were here to find the main street built during the Qing imperial era, they looked at us in confusion and said: "Then why are you here? We know where it is already. Elder folks told us long time ago, it's not here, you guys are searching in the wrong place!" When we shared this event with local amateur historians, we realised that the location of some historic places has been a source of long-term conflict between native elders (born and raised in Zuoying) and local amateurs (mostly from Kaohsiung city but not specifically from Zuoying). The elders became very upset when local researchers provided interpretations of historic documents that directly conflicted with their traditional memories: "Outsiders don't know anything" one of the elders said, "Why would our grandfathers lie to us? Impossible. They (local researchers) are not from here, they don't understand." From this incident, we witnessed some power struggles between the stakeholders. In this case, the native elders were quite powerless compared to the local amateurs, who were more organised and supported their arguments with historic 
records. As such, they could impose their own interpretation of heritage over the local elders.

Amid this conflict, the archaeological team was requested by the locals to "resolve" conflicts around cultural heritage with scientific methods. The excavations carried out at the OCZ site allowed us to delineate the boundaries of the settlement based on the concentration of materials and with the building foundations. But defining the exact location of certain representative structures was not possible. The archaeological team also felt that it was inappropriate to act as judges about a variety of historic and traditional statements.

Instead, we decided to become a bridge between different communities. Instead of aiming for consensus, we wanted to develop the multi-vocality around the site, and to make it a space for debate and shared memory (Castañeda 2008: 53-54; Habu \& Fawcett 2008: 93; Hodder 2008:197). Witnessing the elders' distrust toward outsiders, we asked one local historical researcher, whose family originated from the old settlement, to attend a meeting arranged near the trench. At this meeting, one of the elders and the amateur historian had a long conversation. While they did not agree with each other on all topics, the meeting created future opportunities for more dialogue. As such, we realised that it was very important to simply create a platform for all stakeholders to be involved and for their voices heard and shared.

The visitors to our trench and exhibition had quite a lot of memories to share and talk about, rather than listen to our "archaeological" research results. Parents explained to their children where their ancestors had lived, and elders came to share their perspectives on history and their childhood stories. These different kinds of knowledge might not match the scientific discourse and formatted knowledge of the archaeologist, and may even oppose certain authorised heritage discourses. Yet, a simple brick or porcelain bowl found on site could bring back evocative memories or connections to their grandparents' home. As such, archaeological research and practice need to, and obviously can in this case, establish connections with people's life in the present.

\section{A Community-based Approach Yet to Be Achieved: a self-critical review}

In 2017, we started a smaller-scale excavation of a $4 \mathrm{~m}$ by $6 \mathrm{~m}$ trench at the OCZ site. We recruited several local community members to work together with academic trained archaeologists, as well as veteran workers who used to work in contract archaeology. We had around ten members in the team. This "hybrid" team became the stage for a lot of discussions focusing on history, community, culture, and archaeology on site. Archaeologists would explain how every context should be excavated and the archaeological theory that supported the selected methodology. Community members, instead, would share their view on the contexts and the materials, and introduce our project to the passers-by, while veteran workers would share their digging experience and skills.

As we see economic contribution to local communities to be an important part of community engagement, the members who joined the team were paid for their daily work on the site. Nevertheless, we tried to avoid establishing a hierarchy within the team: the daily routine and schedule were discussed, voted, and organised among all 
team members. However, there is no denying that archaeologists were still in a privileged position to define the methodology and to interpret and guide the research design. This contradiction was one of our permanent struggles in finding balance between maintaining our research principles and giving increasing control to communities. Further, the longer excavation took, the harder it was for academic archaeologists to devote most of their time to the fieldwork. In 2017 and early 2018, two excavations were carried out by academic archaeologists and community members, both lasting one month. However, when we launched a thirty-month excavation in 2018, the team had to extend by hiring full-time assistants without archaeological degrees (they were trained on site by the team), while archaeologists could only take occasional time off from their academic duties to join the fieldwork. This phenomenon inevitably increased the distance of archaeologists from the fieldwork and created tension between team members. The assistants and community members expressed frustration when they encountered difficulties during excavation with archaeologists absent and unable to respond in time. Also, archaeologists noticed the lesser time spent on the site, the fewer thoughts team members were willing to share. Undoubtedly, both the quality of archaeological excavation and the connection between community members and archaeologists were damaged when archaeologists failed to devote enough time on site (if not, all time).

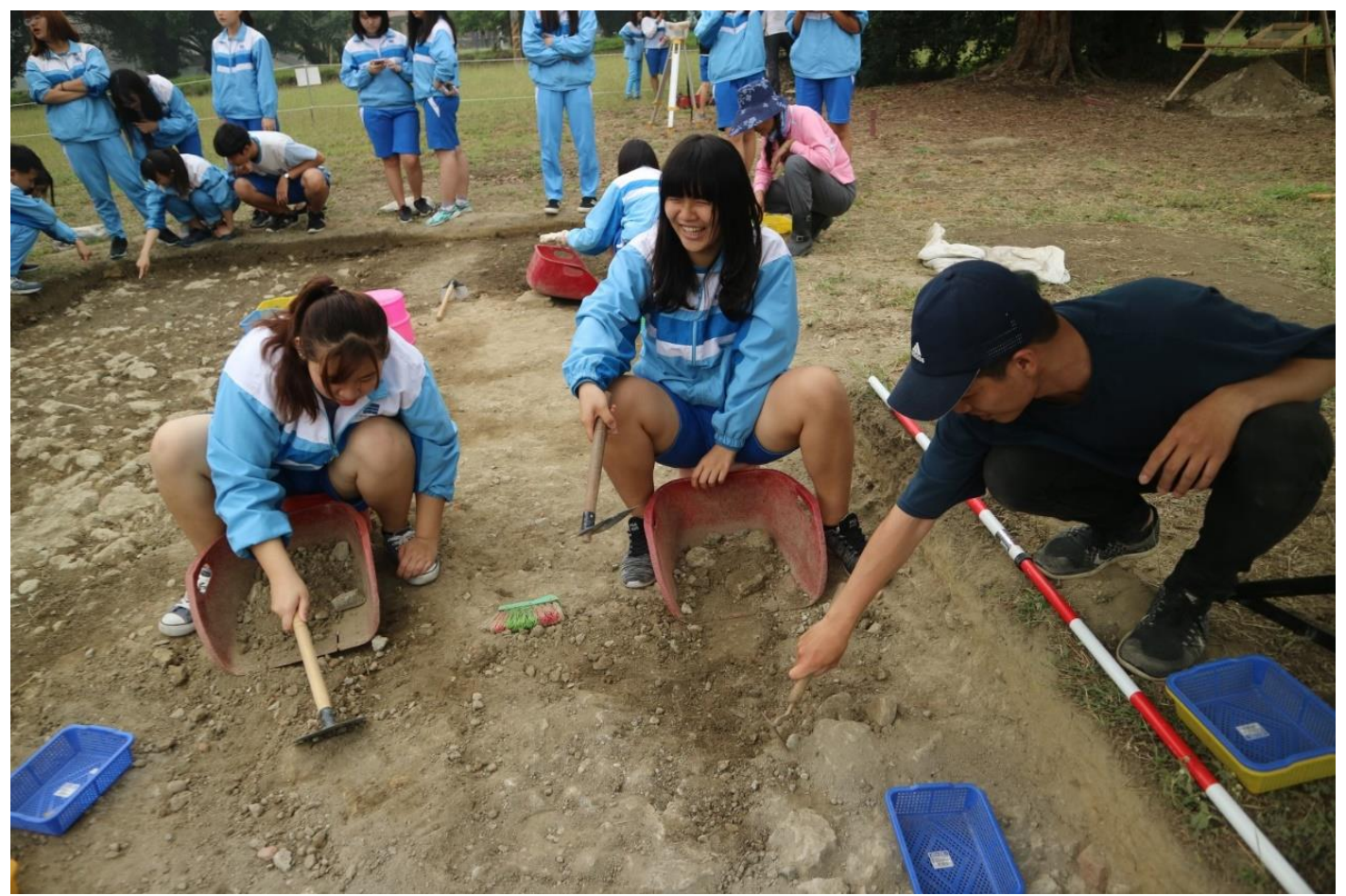

Figure 3. Public outreach during the excavation, with teachers and students from the Kaohsiung Municipal Haiching High School coming to the site and discussing the excavation with the team. (OCZ site, 13 April 2017, Photographer: Bo-Chiao Wang).

In the meantime, in the sense of public engagement, we had some positive outcomes: 1) teachers from local schools brought students to our trench for history classes (Fig. 2); 2) people from the neighbourhood brought pottery sherds they collected near the site 
through the years for us to identify; 3) community members brought their friends to show their involvement in archaeology, and 4) our public outreach events received an overwhelming number of applications from participants all around Taiwan.

However, in the sense of excavation "progress", we did not achieve the initial project goal to reach Qing Dynasty layers. Academic and local researchers expressed their scepticism about the excavation's slow pace and about spending too much time on contexts with lesser significance. We even received some comments about our fieldwork mentioning that we were "fooling around", and that it was "not real archaeology".

Yet, thanks to an additional budget from the city government, we expanded our team to around twenty people, including scholars from archaeology and geology, local historical researchers, community members, and veteran workers. Within an excavation period of twenty months (from 2018 to 2019), we excavated a total of 672 square meters of trenches around the site. We consulted local researchers to excavate at significant locations within the Old City, including the possible locations of the main streets, of some temples, and of the demolished city wall. The excavation was part of the public outreach events every week, with people coming to the trenches and joining the excavation during the afternoon.

As we encouraged team members to discuss history, materials, in addition to archaeological context during the excavation, community members often had insights onto the materials unearthed. For example, they could identify some building materials from the $19^{\text {th }}$ century, and the comparison with similar materials nearby helped us understand usages, type and size of old bricks, tiles, and wall paint. The participation of community members not only brought local knowledge to the team, but it also brought in some welcomed excitement for history and for archaeology. $\mathrm{H}$

However, despite these modest achievements during this community-based project, we did encounter difficulties. The power dynamic between archaeologists and the local communities being the most problematic one, especially considering our goal was to challenge the hierarchy of current practices.

\section{Challenging power?}

Our interactions started smoothly with local communities. Local researchers shared their knowledge and some data, some community members joined the excavation team, and we collaborated in public outreach events from time to time. Nevertheless, at some point, we felt that we could not have the communities participating to a greater degree in the archaeological activities, and even the members who joined the team felt that. It was clear that their friends and peers in the amateur historian community tried to maintain a certain distance. People remained friendly, happy to help when we asked, but they avoided giving opinions or further participating in our work. In a discussion with one of the authors of this paper, one of the community members pointed out what could be the problem:

Community member: "Sometimes it feels like [whatever we do] is merely another NCKU [academic] project. If you really want to produce something with the perspective of the community, like 
what we discussed before, who's going to publish it? Who is the director? Like, you are the one who's running the [archaeology in Zuoying] FB page. All of the work, the recording, is carried out by you. So no, there isn't really an archaeological community."

Bo-Chiao Wang: 'It's contradictory [for archaeologists to want a community to be involved and motivated but also to want to remain in control].

Community member: "Exactly."

$[---]$

Community member: "Yes, like what you said, NCKU provided funding, but then whatever the community is producing, it needs to fit your expectations, and this is weird. So, where is the position of the community in [the practice] ... If the relationship [between the community and the archaeologists] is like that, the community is merely part of your project."

Bo-Chiao Wang: "[you mean we made you feel like] something auxiliary."

Community members were fully aware that we did not truly release our power over them. We did consult for their opinions, but we never truly included them in the process of decision making, and as such we failed to establish a community-based archaeological project. Community members in Zuoying have their own research interests, and the ability and resources to carry out research by themselves: our research aims did not interest them. In the end, it took years for us to realise our mistakes and how we failed to establish a true partnership with the local communities. Nevertheless, this experiment demonstrated that there is no short-cut in community-based research. Archaeologists need to foster long-term commitments to the site and local communities, as well as a self-critical approach. Most importantly, archaeologists must include the communities into every aspect of the research, from archaeological data production to creating narratives.

\section{Concluding Remarks}

In this article, we have illustrated some recent dynamics of archaeological practice in Taiwan by placing it within its complex historical and socio-economic context. Within this framework, we examined how archaeologists are now seeking alternative methodologies.

As mentioned, three research targets were set to build a community-archaeology model: 1) breaking the hierarchy within the team and avoid disengaging archaeologists from the field; 2) empowering team members by granting them access of knowledge and giving them space for interpretation; 3) entering the community and fostering collaborations. We achieved them to some degree, but there is no denying that we also failed in some respects.

Constructive and positive outcomes of this community-based project have been numerous and brought great satisfaction to both archaeologists and local communities in strengthening their relationship and understanding of a specific example of cultural heritage. Not only was a dialogue established between archaeologists and diverse communities, but also between the communities themselves. 
During the excavation, the archaeological site became an area of knowledge and memory sharing between archaeologists, community members, local historical researchers and tourists who visited the site. People came and joined the excavation and interpretated the archaeological contexts and artefacts unearthed with their own perspectives, while archaeologists provided academic knowledge. We built a close connection with the community members who joined our team, and now they are still monitoring the site with an archaeological perspective and have discussions with us from time to time. However, in terms of challenging power relationships and aiming to lose control over the management of the archaeology and share its construction with the public primarily concerned, we mostly failed. As mentioned above, team members felt frustration when archaeologists failed to devote enough time on site, as they became more workers receiving orders from employers than research partners. Other local communities, while remaining friendly, kept their distance from the team as they did not feel truly empowered. The community members expressed their clear feeling as being a co-opted group that ultimately served the interests of the archaeologists, and not their own. Future projects will carefully take these results into consideration and strive to give greater access and control to more community members. In this context, it seems obvious that the sustained presence of archaeologists and their involvement with local communities is not compatible with the dominant archaeological model rooted in capitalism. Future projects will continue to challenge this model and find new ways forward in the dialogue between archaeologists and communities, as well as between the past and present of Taiwan's rich heritage.

Now, from a more distant perspective, considering the multi-layered colonial history of Taiwan, the subject of archaeological heritage has been viewed from a range of often conflicting perspectives. As an example, the presentation of heritage as "Han Chinese" or modified by the KMT regime after 1949 to resemble this interpretation, could be interpreted as a way to justify the colonial domination of Han-Chinese mainlanders through the display of supposed moral and civilisational superiority. For others, especially Han-Chinese natives of Taiwan (i.e. those who arrived between the $17^{\text {th }}$ century and 1945, and their descendants), this heritage could be interpreted more positively in terms of roots, and identity distinctiveness, and much less in terms of socio-political domination, as the latter group was subjugated by the former. In opposition, all the heritage related to the island's Indigenous population, which comprises the large majority of Taiwanese archaeology, has the potential to become a legitimate symbol for defending their rights and for the resurgence of their identities. Moreover, it could be presented to support their claims of regaining control over their land and their destinies. Obviously, heritage in Taiwan has been used or misused in numerous ways, since it was and continues to be instrumental to various forms of nationalisms and/or independentism. Yet, whatever meanings were given to heritage in Taiwan in the past, economic development has taken a dominant position since the 1980s, functioning within an extractivist capitalist framework.

Therefore, the necessity of decolonisation is particularly urgent in Taiwan, where there is an important Indigenous population that has complex and rich connections to most of the island's archaeological heritage. This decolonisation should be urgently implemented within all our archaeological practices, simultaneously aiming at 
deconstructing and challenging its capitalist and colonial roots through community engagement. Our project at the OCZ tried to do this in an historical context and in collaboration with local communities. In the case of Zuoying, our primary objective was to create space for archaeology to interact with contemporary society. Therefore, the connections the archaeological site has with local communities, its material from multiple periods, and its recognition as national heritage gave us an exceptional opportunity to interact with the past in the present. We had to deal with the perspectives and agendas of many different communities, which challenged us to build more multivocal and non-hierarchical ways of collaborating between archaeologists and communities, even though we were not that successful in doing so.

\section{References}

AmAE Y. 2017 Becoming Taiwanese: Appropriation of Japanese Colonial Sites and Structures in Cultural Heritage-Making- A Case Study on the Wushantou Reservoir and Hatta Yoichi. Citizens, in: HSIAO H. H. M., HUI Y. F., PEYCAM P. (eds.), Civil Society and Heritage- Making in Asia. Taipei: Academia Sinica.

Atalay S. 2006 Indigenous Archaeology as Decolonizing Practice. American Indian Quarterly 30: 280-310.

AtAlay S. 2012 Community-Based Archaeology: Research With, By, and For Indigenous and Local Communities. Berkeley: University of California Press.

Blumenfield T. \& Silverman H. 2013. Cultural Heritage Politics in China. New-York, London: Springer.

Bonacchi C. \& Moshenska G. 2015. Critical Reflections on Digital public archaeology, Internet Archaeology 40. Doi: org/10.11141/ia.40.7.1

Castañeda Q.E. 2008. The "Ethnographic Turn" in Archaeology, in: Castañeda Q.E. \& MATTHEws C.N. (eds.), Ethnographic Archaeologies: Reflections on Stakeholders and Archaeological Practices. Lanham: AltaMira Press: 27-63.

CHANG K.C. 張光直. 1977. Zhuoda jihua yu minguo liuyi liusan nian zhuoda liuyu kaogu diaocha 濁大計畫與民國六一 六三年濁大流域考古調查, in: CHANG K.C. (ed.), Taiwan sheng shuoshui xi yu dadu xi liuyu kaogu diaocha baogao

臺灣省濁水溪與大肚溪流域考古調查報告. Taipei: Academia Sinica: 1-26.

CHANG K.C. 張光直. 1986. Taiwan shi tianye yanjiu tongxun fa kan ci

臺灣史田野研究通訊發刊詞. Newsletter of Taiwan History Field

Research臺灣史田野研究通訊. 1: 1 .

CHEN M.L. 陳瑪玲. 2005. The SettlementPatterns and Configurations of SaqacengaljArchaeological Study on An Abandoned Settlement. The Bulletin of the Department of Archaeology and Anthropology. 63: 50-91.

CHEN M.L. 陳瑪玲. 2013. Kaoguxue jiushe yanjiu de qianli yi taiwan nan paiwan gaoshi jiushe de yanjiu weili

考古學舊社研究的潛力一以臺灣南排灣高士舊社的研究為例. Relics from south 3: 94-101. 
CHEN Y.M. 陳玉美. 1996. Wenhua jiechu yu wuzhi wenhua de bianqian yi lanyu yamei zu weili 文化接觸與物質文化的變遷：以蘭嶼雅美族為例. Bulletin of the National Research Institute of history and philology Academia Sinica. 67(2): 415-434.

CHEN Y.M. 陳玉美. 2003. Kăo gǔ xué zhōng rén yǔ huán jìng guān xì de yán jiù yǐ Site Catchment wéi lì 考古學中人與環境關係的研究：以 Site Catchment為例. Bulletin of the Department of Anthropology National Taiwan University. 60: 97-114.

CHUnG K.F. 鍾國風 2014. 'The Social Life of Ritual Pottery: An Ethnological Survey in an Amis Community of Dongchang and Archaeological Research of Jingpu Culture', $\mathrm{PhD}$ thesis, National Chengchi University.

CHUnG K.F., LIU Y.C., CHAO C.Y., WANG S.C. \& WANG B.C. 鍾國風. 劉益昌. 趙金勇. 王淑津. 王柏喬. 2017. Shoushan guojia ziran gongyuan shiji buobua liyong baocun ji zhanshi jihua- daxiao guishan ji zuoying jiucheng diqu壽山國家自然公園史蹟活化利用保存及展示計畫- 大小龜山及左營舊城地區. Kaosiung: National Nature Park.

Colwell-Chanthaphonh C. \& Ferguson T.J. (eds.), 2008. Collaboration in Archaeological Practice - Engaging Descendant Communities. Lanham: AltaMira Press.

DENZIN N.K. 2009. The Research Act: A Theoretical Introduction to Sociological Methods. New Brunswick: Aldine Transaction.

FrITS J.M. \& PlOG F.T. 1970. The Nature of Archaeological Explanation. American Antiquity 35(4): 405-412.

HABU J. \& FAWCETT C. 2008. Science or Narratives? Multiple Interpretations of the Sannai Maruyama Site, Japan, in: HABU J., FAwCETt C. \& MAtSunAgA J.M. (eds.), Evaluating Multiple Narratives: Beyond Nationalist, Colonialist, Imperialist Archaeologies. New York: Springer: 91-117.

Ho C.K., LiU K.H., ZHENG J.W. \& CHEN H.W. 何傳坤. 劉克泣. 鄭建文. 陳浩維. 2001. Gaoxiong shi zuoying yizhi fanwei ji baocun jią̧bi yanjü ji bua qimo baogao

高雄市左營遺址範圍及保存價值研究計畫期末報告. Kaohsiung: Kaohsiung City Government.

HodDer I. 2000. Toward Reflexive Method in Archaeology: The Example at Catalhöyük. Cambridge: McDonald Institute for Archaeological Research.

Hodder I. 2003. Archaeological Reflexivity and the "Local" Voice. Anthropological Quarterly. 76(1): 55-69.

HodDer I. 2008. Multivocality and Social Archaeology, in: HABU J., FAWCETT C. \& Matsunaga J.M. (eds.), Evaluating Multiple Narratives: Beyond Nationalist, Colonialist, Imperialist Archaeologies. New York: Springer: 196-200.

HolTORF C.J. 2007. Archaeology is a Brand: The Meaning of Archaeology in Contemporary Popular Culture. Walnut Creek: Left Coast Press.

Hutchings R.M. 2018. Meeting the Shadow: Resource Management and the McDonaldization of Heritage Stewardship, in: WeLls J.C. \& STIEFEL B.L. (eds.), HumanCentered Built Environment Heritage Preservation. New York: Routledge: 67-87.

Hutchings R.M. \& LA SALLE M. 2015. Archaeology as Disaster Capitalism. International Journal of Historical Archaeology: 699-720. 
KANO T. 鹿野忠雄1952 Sanshigaku yori mitaru tounan ashiia nio keru udenawan no 先史學より見たる東南亞細亞に於ける臺灣の. Tounanasaiamin rokugaku senshigaku kenkyun 東南亞細亞民族學先史學研究 2: 89-187.

Kendall L. 2010. Consuming Korean Tradition in Early and Late Modernity - Commodification, Tourism, and Performance. Honolulu: University of Hawai'i Press.

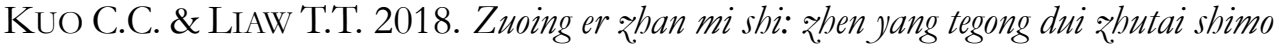
左營二戰祕史：震洋特攻隊駐臺始末. New Taipei: Walkers Cultural Enterprise.

KUO S.C., TAI R.C., YUAN C.L., CHENG T.J., Wu M.J. 郭素秋. 戴瑞春. 袁進龍. 陳得仁. 吳美珍. Laofo yizhi diaocha yanjiu jibua baogao 老佛遺址調查研究計畫報告. Pingtung: Pingtung county government.

LA SALLE M. 2010. Community Collaboration and Other Good Intentions. Archaeologies 6(3) (Journal of the World Archaeological Congress): 401-422.

La SAlLE M. \& Hutchings R.M. 2016. What Makes Us Squirm - A Critical Assessment of Community-Oriented Archaeology. Canadian Journal of Archaeology/ Journal Canadien d'Archéologie 40: 164-180.

LA SAlLE M. \& HutChings R.M. 2018. What Could Be More Reasonable? Collaboration in Colonial Contexts, Oxford Handbooks Online (April 2018), DOI: 10.1093/oxfordhb/9780190676315.013.22.

LIAW D.T. 2014. Qing dai fengshan xian jiucheng nei simiao guanshu yu jiedao kongjian zhi kaozheng. 清代鳳山縣舊城內寺廟、官署與街道空間之考證. Kaobsiung Historiography: 101-134.

LINNEKIN J. 1997. Consuming Cultures: Tourism and the Commoditization of Cultural Identity in the Island Pacific, in: PICARD M. \& WOOD R.E. (eds.), Tourism, Ethnicity, and the State in Asian and Pacific Societies, Honolulu: University of Hawai'i Press: 215-250. LiTTLE B.J. \& SHACKEL P.A. 2007. Archaeology as a Tool of Civic Engagement. Lanham: AltaMira Press.

LIU Y.C. 劉益昌. 1995. Shiqian wenhua yu yuanzhumin guan xi chubu tantao 史前文化與原住民關係初步探討. The Taiwan Folkways 45(3): 75-98.

LIU Y.C.劉益昌. 2002. Taiwan yuanzhumin shi shi qian pian 臺灣原住民史史前篇. Nantou: Taiwan Historica.

LIU Y.C.劉益昌. 2006. The Discipline of Taiwanese Archaeology and Studies of Indigenous People Groups. Bulletin of the Department of Anthropology National Taiwan University 66: 70-93.

LIU Y.C.劉益昌. 2008. Lishi de zuoying jiaobu 歷史的左營腳步. Kaosiung: Kaohsiung City Government.

LiU Y.C., Tseng Y.H., Chung K.F., Shiung C.C., Lin K.Y., Wang B.C., Lin C.H., YAnG C.W. \& LIANG Y.Y. 劉益昌. 曾義星. 鍾國風. 熊仲卿. 林冠穎. 王柏喬. 林佳萱. 楊慶瑋. 梁詠喻. 2021. Gaoxiong shi zuoying qu fengshan xian jücheng chengnei kongjian kaogu diaocha fajue ji zhanshi yanjiu jïbua.

高雄市左營區鳳山縣舊城城內空間考古調查發掘暨展示研究計畫. Kaohsiung: Kaohsiung City Government.MATsudA A. \& MEngOni L.E. (eds.), 2016. Reconsidering Cultural Heritage in East Asia. London: Ubiquity Press. 
McGuire R.H. 2008. Archaeology as Political Action. Berkley: University of California Press.

Merriman N. 2004. Public archaeology. London: Routledge.

Moshenska G. 2010. What is Public Archaeology? Present Pasts 1(1). DOI:

http://doi.org/10.5334/pp.7

MUYARD F. 2016. Taiwan Archaeology and Indigenous Peoples: Cross-perspectives on Indigenous Archaeology and Interactions between Archaeologists and Indigenous Communities, in: Hung L.W. (ed.), Archaeology, History and Indigenous Peoples: New Perspectives on the Ethnic Relations of Taiwan. Taipei: Shung Ye Museum of Formosan Aborigines: 195-262.

NAKANO R. \& ZHU Y. 2020. Heritage as soft Power: Japan and China in international politics. International Journal of Cultural Policy 26 (7): 869-881.

Okamura K. \& Matsuda A. (eds.), 2011. New Perspectives in Global Public Archaeology.

New-York, London: Springer.

Overholtzer L. 2015. A Model for Initial Implementation of a Collaborative

Archaeology Project. Advances in Archaeological Practice 3 (1): 50-62.

PALMER C. 2001. Ethnography: A Research Method in Practice. International Journal of Tourism Research 3: 301-312.

Pyburn K.A. 2011. Engaged Archaeology: Whose Community? Which Public? in:

OkAmura K. \& Matsuda A. (eds.), New Perspectives in Global Public Archaeology. New-

York, London: Springer: 29-41.

Shanks M. 2005. Public Archaeology/Museology/Conservation/Heritage, in:

RENFrew C. \& BAhn P. (eds.), Archaeology: The Key Concepts. London: Routledge: 164-167.

SuNG W.H. 宋文薰. 1965. Taiwan xibu shiqian wenhua de niandai臺灣西部史前文化的年代. Taiwan Historica. 16(4): 144-155.

TSANG C.H., GAO Y.D. \& LIU Y.C. 减振華. 高有德. 劉益昌. 1988. Taiwan zaoqi hanren ji pingpu zu juluo de kaogu xue yanjü jïhua di yi nian du yanjiu jindu baogao

臺灣早期漢人聚落暨平埔聚落的考古學研究計畫第一年度研究進度報告. Taipei:

National Council on Science Development.

TsANG C.H., GAO Y.D. \& LIU Y.C.諴振華. 高有德. 劉益昌. 1993. Zuoying qingdai fengshan xian jiucheng juluo de shijue. 左營清代鳳山縣舊城聚落的試掘. Bulletin of the Institute of History and Philology Academia Sinica. 64(3): 763-865.

WANG B.C. 2020 王柏喬 'Reflexivity and Social Practice in Archaeology: Community Archaeology in Qin Empire Era Fongshan-Old-City site'. Master thesis. National Cheng Kung University.

Wu M.C. 吳牧錞 2013. Settlement Space and Neighbourhoods: Applying Computing Archaeology in Saqacengalj, Taiwan. The Bulletin of the Department of Archaeology and Anthropology. 79: 71- 104.

YEN T.Y. 顏廷伃2014. Zhanding guji fengshanxian jiucheng ximen duan chengmen ji chengqiang yuji kaoguxue qingli jihua 暫訂古蹟鳳山縣舊城西門段城門及城牆遺跡考古學清理計畫. Kaohsiung: Kaohsiung City Government. 
YEN T.Y. 顏廷伃2015. Yuan xi zizhu xincun fengshanxian jüucheng ximen duan chengnei kongïan kaogu shijue ji yanjiu jïhua

原西自助新村（鳳山縣舊城西門段城內空間）考古試掘及研究計畫. Kaohsiung: Kaohsiung City Government.

YEN T.Y., Hsu S.F. 顏廷伃. 許勝發 2013. Wangjia jiushe rentougujia yizhi qiangizu diaocha jibua 望嘉舊社人頭骨架遺址搶救調查計畫. Pingtung: Pingtung county government. ZIMMERMAN L.J. 1997 Remythologizing the Relationship between Indians and Archaeologists, in: SwIDler N., Dongoske K., ANYON R. \& Downer A. (eds.), Native Americans and Archaeologists: Stepping Stones to Common Ground. Walnut Creek: AltaMira Press: 44-66.

Zimmerman L.J. 2008. Unusual or "Extreme" Beliefs about the Past, Community Identity, and Dealing with the Fringe, in: COLWELL-CHANTHAPHONH C. \& FERGUSON T.J. (eds.), Collaboration in Archaeological Practice - Engaging Descendant Communities. Lanham: AltaMira Press: 55-86.

ZORZIN N. forthcoming. A Review of Archaeological Organisation and Practices in Taiwan. The Journal of the Archaeological Society of Taiwan [臺灣考古學會] ZORZIN N. 2021. Is archaeology conceivable within the degrowth movement? Archaeological Dialogues 28(1): DOI: 10.1017/S1380203821000015: 1-16.

ZORZIN N. 2020. Alternating Cycles of Politics of Forgetting and Remembering the past in Taiwan, in: APAYDIN V. (ed.), Critical perspectives on cultural memory and heritage. Construction, transformation, and destruction. London: UCL Press: 269-288. 